\title{
Assessment of Alternative Rural Energy Sources and Technologies in South-Eastern Oromia Region, Ethiopia
}

\author{
Tamrat Gebiso Challa* \\ Socioeconomics Research Directorate, Oromia Agricultural Research Institute \\ PO box 06, Asella Agricultural Research Center, Asella \\ Ayalew Bekele \\ Agricultural Engineering Research Directorate, Oromia Agricultural Research Institute \\ PO box 06, Asella Agricultural Research Center, Asella \\ Ibsa Dawud \\ Socioeconomics Research Directorate, Oromia Agricultural Research Institute \\ PO box 06, Asella Agricultural Research Center, Asella
}

\begin{abstract}
Majority of world population ( $80 \%$ of total world) is living in rural area but consumes only about $30 \%$ of global commercial energy. In rural developing nations the energy sources for cooking and lighting are traditional sources with more prevalence in rural areas. Specially in Ethiopia, literatures indicated that more than $94 \%$ of the energy sources are from traditional sources. Poverty, lack of availability of modern energy and lack of education are the main causes of this phenomenon. Abundance use of biomass fuel with inefficient stoves caused scarcity of biomass resources in Ethiopia. However, in the study areas, namely Arsi and west Arsi, biomass energy sources and other energy sources and technologies under utilization were not characterized for research and development intervention. Therefore, this research proposal was initiated with objectives of characterizing energy resources and technologies under utilization and related constraints in the study areas. Four districts from Arsi and three districts from w/Arsi zones were selected and data was collected through FGD, KII and household level survey. The result revealed that majority of rural households are using biomass fuel (wood, animal dung and crop residues) specially for cooking purposes and there is expansion of solar cells for lighting purposes. The biogas plant use was under demonstration stages and it was also constrained with high capital investment and its accessory technology (injera stove).development of energy plants like jathropha is also underway in lowlands of Arsi zone.
\end{abstract}

Keywords: "rural energy, biomass fuel, pure energy, improved cook stoves, Arsi zone"

DOI: $10.7176 / \mathrm{JETP} / 9-2-01$

\section{Introduction}

More than half of world population, which is about three billion, has no access to modern sources of energy. These peoples are poor and their predominant energy sources are traditional biomasses (Dawit D. Guta, 2012). Access to efficient and modern energy is extremely crucial for the developing nations to counter the economic and health issues and at the same time with the productive use of energy increase the economic growth and life standard of the poor people. Developing countries have $80 \%$ of the world's population but consume only $30 \%$ of global commercial energy (Eric Martinot et.al, 2002). A well performing energy system can provide these people with income generating opportunities as well as to escape them from the awful impacts of poverty. Unfortunately this has not been made possible due to financial issues, lack of resources, ineffective energy policies and energy systems in the developing nations.

Dependency of the people on traditional energy for catering their cooking and lighting energy demands in the developing nations still prevails especially in rural areas. Poverty, lack of availability of modern energy and lack of education are the main causes of this phenomenon. Abundant use of biomass for meeting the demands also brings the scarcity of these resources like fuel wood. However, due to gradual increase in awareness of the people demand for electrification in Ethiopia is increasing to around 20 percent per annum (Samson T., 2016).

Ethiopia's energy consumption as one of developing countries is predominantly based on biomass energy sources. An overwhelming proportion (94\%) of the country's energy demand is met by traditional energy sources such as fuel wood, charcoal, branches, dung cakes and agricultural residues and nearly 2 percent of the population of Ethiopia has an access to grid electricity. The balance is met by commercial energy sources such as electricity and petroleum. The most important issue in the energy sector is the supply of household fuels, which is associated with massive deforestation and the resultant land degradation. The increasing scarcity of fuel wood is compounded by Ethiopia's high population growth rate.

Another detriment side of utilizing energy in inefficient way is higher consumption of energy than usually required with disastrous health effects due to smoke. Smith et al., 2000 in their study indicated that fuel wood, roots, agricultural residues and animal dung are all producing high emissions of carbon monoxide, hydrocarbons 
and particulate matter. Access to modern and clean energy like electricity and efficient cooking technologies to the rural areas in developing world not only provide improved and healthy life style but would also help in reducing harmful environmental effects. Efforts on the all levels are required to counter this situation with effective projects and policies on government level as well as awareness of the uneducated masses in the rural developing world. In general this activity is initiated to conduct a situation analysis for characterizing the sources of energy and technologies used in rural areas for research and extension intervention.

The main objective of this study was to assess and analyze the existing energy resources in the area while the specific objectives of the study were: to characterize and analyze the existing energy resources, to identify and prioritize challenges and constraints of the energy resources, to identify and prioritize potential opportunities of the energy resources and to identify and prioritize potential research intervention areas to connecting the existing opportunities of the energy resource of the study area

\section{Methodology}

\section{Description of the study areas}

The research was carried out in south-east areas of Oromia regional state. This area of the region is one of the most productive clusters of the region. Two zones namely Arsi and w/Arsi were selected purposively based on accessibility. Each zone was clustered into three based on major agro-ecologies as lowland, midland and highland and sample districts were selected from each cluster.

Arsi zone is divided into twenty-five administrative districts and one administrative town (Asella). It is located in 37N 555133.09766783 856692.23862263 UTM coordinates. The zone has four agro-climatic zones and altitude is the main source of difference. These diverse agro-climatic conditions create wider opportunities of having different vegetation which are sources of biomass energy.

West Arsi zone is also divided into eleven administrative districts and one administrative town (Shashamane which is the capital town of the zone. West-Arsi zone has land area of about 1,177,440 hectares or 12,938 km2. Crop-livestock mixed farming and pastoral and agro-pastoralism are commonly practiced in all highlands, and mid and lowlands. According to data from zonal agricultural development office and discussion held with agriculture and rural development office experts, typical highlands of some districts like Dodola and Adaba and lowlands have both pastoral and agro-pastoral farming system.

\section{Sample and Sampling Methods}

On the basis of agro-ecology diversity, representative districts, peasant associations (PAs) and participant farmers were selected using systematic sampling technique. Then, from the identified PAs/villages, representative farmers were randomly selected for group discussion and interviews using systematic sampling procedure. During sampling for focus group discussion and household level interview, age-sex composition, educational status, roles and responsibilities in the community were taken into consideration. A multi-disciplinary team was established to conduct the survey using different PRA tools.

\section{Data types and methods of data collection and analysis methods}

Both primary and secondary data were collected from different sources at different levels. Primary data were generated through focus group discussion, individual interviews, and formal and informal discussions with farmers, DAs and experts. Focus group discussions, key informant interview and informal discussion were among the employed tools to collect primary data using checklist and semi-structured questionnaire.

Different PRA tools were employed to collect information on different aspects of existing biomass fuel resource of the study area including semi-structured interviews, focus group discussions and personal observations were employed to generate primary data pertaining to the existing biomass fuel resource in the study area. Focus group discussion was employed to get about the existing biomass fuel resource, prevailing opportunities and constraints, with key informants (farmers, DAs, community leaders). In general a total of 329 households were sampled from seven districts of which three were from west Arsi and the rest four were from Arsi zone. Around 45 percent and 55 percent of the respondents were from Arsi and west Arsi zone respectively. The collected data was analyzed using appropriate statistical tools to fulfill the objectives of the study. The quantitative data was analyzed using descriptive statistics like mean, standard deviations frequency and t-test using statistical package for social sciences (SPSS) for analysis.

\section{Result and Discussion}

\section{Demographic and Socioeconomic Characteristics of the Respondents}

Mean age of respondents was 45.50 years which within working age group. Around 5 percent of the households were female headed and the rest 95 percent were male headed. More than 98 percent of the respondents were married while only around one percent of the respondents were widowed. The overall average family size of the households was 7.92 persons per a household while the mean male family members and female family members 
were 4.27 and 3.64 persons per household respectively (table 1).

Table 1: Demographic and Socioeconomic Variables of the Respondents

\begin{tabular}{lllllc} 
Variable & N & Mean & Std. Deviation & Min. & Max. \\
\hline Age & 329 & 45.50 & 11.99 & 22 & 78 \\
Education & 329 & 4.10 & 3.48 & 0 & 11 \\
Total male family & 329 & 4.27 & 2.25 & 1.00 & 14.00 \\
Total female family & 329 & 3.64 & 2.12 & 0.00 & 13.00 \\
Total Family & 329 & 7.92 & 3.53 & \multicolumn{2}{c}{0} \\
\hline & $\mathbf{N}$ & & Percent & Cumulative percent \\
Male headed & & 313 & & 95.10 & 95.10 \\
Female headed & & 16 & 4.9 & 100 \\
Married & 324 & 98.5 & 98.50 \\
Single & 1 & 0.3 & 98.80 \\
Widowed & 4 & 1.20 & 100.00 \\
\hline
\end{tabular}

Source, own survey result, 2017

It was tried to balance the sample from each agro-ecological zones. Accordingly, 43.20 percent of the respondents were from highland areas while around 32 percent and 25 percent of the respondents were from midhighlands and lowlands respectively (table 2)

Table 2: Respondents Distribution across Agro-ecologies

\begin{tabular}{lllc} 
Agro-ecology type & N & percent & cumulative percent \\
\hline Highland & 142 & 43.2 & 43.2 \\
Mid-highlands & 105 & 31.9 & 75.10 \\
Lowland & 82 & 24.9 & 100
\end{tabular}

The educational background of the respondents was assessed using years of education. The mean year of education was 4.07 years with standard deviation of 3.48. Family labor force was calculated as man-equivalent of the family members and the mean family labor was 3.59 man-equivalents. Total mean of labor-to-land ratio was calculated to be 4.41 man-equivalents to a hectare of land. That means, on average 4.41 full labors is working on a hectare of land (table 3).

Table 3: Landholding and land use pattern of the sampled respondents in the Study Area

\begin{tabular}{|c|c|c|c|c|c|}
\hline & $\mathrm{N}$ & Min. & Max. & Mean & Std. Dev. \\
\hline Man-equivalent of family labor & 329 & .60 & 15.40 & 3.59 & 2.05 \\
\hline Rain-fed crop land size & 329 & .00 & 8.00 & 1.40 & 1.22 \\
\hline Labor to land ratio & 323 & .16 & 18.5 .00 & 4.41 & 11.80 \\
\hline Forest land size & 329 & .00 & 1.00 & 0.02 & 0.12 \\
\hline Degraded land size & 329 & .00 & 1.00 & 0.02 & 0.11 \\
\hline Land for residence & 329 & .00 & 1.50 & 0.20 & 0.20 \\
\hline Total landholding & 329 & .00 & 11.00 & 1.82 & 1.58 \\
\hline Livestock (TLU) & 329 & .00 & 40.85 & 5.78 & 5.27 \\
\hline Total annual income & 329 & 100 & 180,000 & 19230 & 2719 \\
\hline \multicolumn{6}{|c|}{ Economic Status of the Respondents } \\
\hline Level & Num & & Percent & \multicolumn{2}{|c|}{ Cumulative percent } \\
\hline Model & 50 & & & & 15.20 \\
\hline Middle & 216 & & & & 80.90 \\
\hline Resource poor & 63 & & & & 100.00 \\
\hline
\end{tabular}

Resource ownership of the respondents

According to local and office of agriculture and natural resource development, the households are generally classified as model, middle level and resource poor farmers in terms of their resource ownership. Accordingly, only 15 percents of the households are classified as model while the rest $65.7 \%$ and $19.1 \%$ were classified as middle level and resource-poor respectively. The total mean land holding of the households was $1.82 \mathrm{ha}$ per a household and the land. Mean family labor was around 3.6 man-equivalents per household. Each household possessed around six (6) units of tropical livestock (table 3). The average annual household income was around 19,000 ETB. Only around seven percent of the households are using electricity and around 69 percent are using mobile phone (table 4). 
Table 4: Household facility holding of respondents in Arsi and W/Arsi zones

\begin{tabular}{llll} 
& Facility type & Frequency & percent \\
1. & Have electricity & 22 & $6.70 \%$ \\
2. & Have telephone & 226 & $68.70 \%$ \\
\hline
\end{tabular}

\section{Major Energy Sources and Energy saving Technology Use patterns in Arsi and West Arsi}

Water, mine and energy office is established at each zone and district level with the major objectives of 1) improving the livelihood and quality of life of rural households through the exploitation of market and non-market oriented biogas sector, 2) to aware and introduce biogas technologies to build capacity of disseminators through training and enhancing skill and knowledge of participants, 3) to develop a commercially viable domestic biodigester and dissemination of technologies, 4) to create access to grid electric light to rural community in collaboration with Ethiopian electric power cooperation (EEPCO).

All respondent households are using multiple sources of biomass and other energy sources. The household level survey result revealed that the most widely used biomass energy sources were round wood, animal dung, crop residues and branch leaf and twigs (BLT) and each of them were selected by $50.2,46.5 \%, 41.3 \%$ and $35.3 \%$ of the respondents respectively. Around $33 \%$ of the respondents buy supplementary energy sources while the rest are using from their own forest trees (mostly eucalyptus tree) farm, crop residues and animal dung. Considerable households are using community forest (around 50.8 percent) for household energy sources. Majority of the households, more than 91 percent of the respondents, fetch biomass energy sources and wives and daughters (the female groups) are the major responsible family members to fetch fire wood and other energy sources each accounting for $82.4 \%$ and $59.0 \%$ of total respondents (table 5 ).

\section{Table 5: Energy Sources, technology use and household responsibility}

No. Energy sources

\begin{tabular}{llll} 
Frequency & & percent \\
\hline 165 & & 50.2 & \\
153 & & 46.5 & \\
182 & & 55.3 & \\
167 & & 50.8 & \\
183 & & 55.6 & \\
& 271 & & 82.4 \\
194 & & 59.0 & \\
157 & & 47.7 & \\
& 38 & & 11.60 \\
& 274 & & 83.30 \\
& 4 & & 1.20 \\
& 212 & & 64.40 \\
& 71 & & 21.60
\end{tabular}

1. Round wood

2. Animal dung

3. Crop residues

4. Use forest as household energy sources

5. Husband is responsible to fetch firewood

6. Wife is responsible to fetch firewood

7. Daughters are responsible to fetch firewood

8. Boys responsible

9. Have improved cooking stove

10. Use 3-stone open cooking stove

11. Use enclosed clay stove

12. Have separate cooking room (kitchen)

13. Use any technology that improve efficiency of biomass

Source: own survey result, 2018

Trend in use of biomass energy sources was assessed through household individual interview. Since the last five years wood (specially the round ones) was the most commonly and extensively used energy source that was ranked as first and followed by animal dung and crop residues with amount of 56.2\%, 42.6\% and 35.6\% respectively (table 5).

Table 6: Energy use patterns across major agro-ecologies

\begin{tabular}{llllll} 
& Highland & Mid-highland & Low-land & & \multirow{2}{*}{ Total } \\
\hline Energy source & Yes & Yes & Yes & $\chi^{2}$ & \\
\hline Firewood & $137(96.5)^{\mathrm{a}}$ & $98(93.3)$ & $70(85.4)$ & $9.6^{* * *}$ & \\
Charcoal & $38(26.8)$ & $59(56.2)$ & $9(11)$ & $46.51^{* * *}$ & $305(92.7 \%)$ \\
Animal dung & $115(81)$ & $73(69.5)$ & $48(58.5)$ & $13.3^{* * *}$ & $106(32.2 \%)$ \\
Liquid petroleum gas & $28(19.7)$ & $33(31.4)$ & $49(59.8)$ & $37.7 * * *$ & $110(33.4 \%)$ \\
Biogas & $4(2.8)$ & $1(1.0)$ & $0(0)$ & 3 & $5(1.50 \%)$ \\
Crop residue & $25(17.6)$ & $79(75.2)$ & $78(95.1)$ & $152^{* * *}$ & $182(55.3 \%)$ \\
Electricity & $7(4.9)$ & $11(10.5)$ & $3(3.7)$ & $4.47^{*}$ & $21(6.4 \%)$ \\
Solar cell & $59(41.5)$ & $40(38.1)$ & $7(8.5)$ & $28^{* * *}$ & $106(32.2 \%)$ \\
\hline
\end{tabular}

${ }^{a}$ numbers in parenthesis are percent of particular energy source users from population in the particular agroecology

$*$, *** chi-square is significant at $90 \%$ and $99 \%$ level of significance

The use of firewood is high in all agro-ecologies with minimum great value in lowland areas. The result from table 6 revealed that around $97 \%$ of highland respondents are using firewood while in lowland area it is little lower to $85 \%$. The use of crop residue as household energy source is also highest in low land where it is the main energy 
source for $95 \%$ of the households. The use of liquid petroleum gas for house lightening is common all areas but it is highly practiced in lowland areas (around 60\%). In highland areas, the culture of using solar cell for lightening is increasing through time (42\%) and substituting liquid petroleum gas.

Table 7: energy sources and technologies used for household lighting

Tech used for light Frequency Percent Cumulative

\begin{tabular}{llllll}
\hline 1. & Electric & 21 & 6.4 & 6.4 & \\
2. & Solar & 91 & 27.7 & 34.1 & \\
3. & Torch & 46 & 14.0 & 48.1 & \\
4. & Biogas & 1 & .3 & 48.4 & \\
5. Kerosene & 170 & & 51.67 & 100.0 & 100.0 \\
\hline
\end{tabular}

Source: own survey result, 2017

As it is revealed in table 7, majority of the households are using kerosene for lighting purpose which is around 52 percent of total households. The use of small scale solar cell was also much considerable, which is about 28 percent of the total households.

\section{Households' kitchen use characteristics}

More than 64 percent of the respondent households have separate cooking rooms (kitchens) facilities while the rest have no separate rooms for cooking purposes and the use of improved technologies (improved cook stoves) are very limited and only 11.6 percent of the households are using improved cook stoves called mirt/gonzie for injera baking which are proven to save biomass energy. During focus group discussion respondents explained that they even can cook outside home in open air during the winter period. In general only around 22 percent of the respondents are using improved cook technologies like mirt (for injera baking) and charcoal saving stoves for stew and coffee making (table 5). The result from Arsi zone's office of energy also shows that the percent of households using improved cook stove are only $10 \%$ and it is almost the same with that of survey result.

\section{Household Energy Consumption and their determinant factors in Study Area}

Estimate of household's daily and annual energy consumption was assessed during survey and presented in table 8. As expected the major sources of biomass fuel were fuel round wood, crop residue and animal dung. The annual consumption of biomass fuel per a household was $759.20 \mathrm{Kg}$ (which is $2.08 \mathrm{Kg}$ per day per household) of wet fuel wood, $620.50 \mathrm{Kg}$ of dry fuel wood $(1.70 \mathrm{Kg}$ per day), and $430.70 \mathrm{Kg}$ of dry crop residue $(1.18 \mathrm{Kg} / \mathrm{day})$. Nearly a liter of kerosene is being consumed per month per each household mainly for house lightening purpose.

Table 8: Annual Household Energy Consumption

\begin{tabular}{|c|c|c|}
\hline Energy sources & Daily Consumption & Annual Consumption \\
\hline 1. Round fuel wood $(\mathrm{Kg})$ & 1.89 & 689.85 \\
\hline 2. Branch Leaf and Twigs & 0.83 & 301.13 \\
\hline 3. Crop residue & 0.83 & 301.13 \\
\hline 4. Animal dung & 0.88 & 319.38 \\
\hline 5. Charcoal & 0.24 & 87.6 \\
\hline 6. Kerosene (lit.) & 0.03 & 10.95 \\
\hline 7. Electricity (KWh) & 0.09 & 32.85 \\
\hline
\end{tabular}

The amount and type of energy sources and use of improved cook stove technologies are determined by different socioeconomic factors. The use of improved cook stoves like improved biomass saving "injera baking" stoves, solar panels and electricity were highly determined by households' income amount. The mean income for ICS, solar energy panel and electricity users were 30521.88, 31208.83 and 31,615.00 while they were 18014.4, 12794.21 and 18600.85 for non-users with t-value significant at 95,99 and 90 percent of probability respectively (table 9).

Table 9: Income and choice of energy technologies

\begin{tabular}{|c|c|c|c|c|}
\hline \multirow{2}{*}{$\frac{\text { Variable }}{\text { Income for: }}$} & & Improved cook stove & Solar panel & Electricity \\
\hline & Users & 30521.88 & 31208.83 & 31615.00 \\
\hline & Non-users & 18014.40 & 12794.21 & 18600.85 \\
\hline & $\mathrm{t}$-value & $2.49 * *$ & $6.18 * * *$ & $2.10^{*}$ \\
\hline
\end{tabular}

The choice of cooking or lightening energy sources was influenced by other factors like family size, age land holding and livestock possession. As an indicator, households' daily fuel wood and animal dung consumption were regressed against different socioeconomic variables like natural logarithm transformed income, family size, man-equivalent family labor, livestock possession in TLU, age of respondent and landholding size of the households. The amount of fuel wood consumption was significantly and positively influenced by family size and 
livestock possession (TLU) while it was negatively influenced by natural logarithm of income and man-equivalent of family labor. The amount of animal dung used was also positively and significantly influenced by landholding and negatively by family labor.

The results from table 9 and 10 reveal that as household income increases, there is a shift from traditional energy sources and combustion technologies to modern and improved and efficient technologies. The amount of daily fuel wood consumption was negatively affected by the amount of household income which shows that there is a shift from traditional energy sources to modern ones like electricity and solar. This result is similar with Bansal et al. (2013) in rural India, Chaudhuri and Pfaff (2003) in Pakistan, Heltberg (2005) in Guatemala and Nlom and Karimov (2014) in northern Cameroon which shows that household income is one of the main factors in choosing fuels for cooking. Ouedraogo (2006) in his findings while analyzing urban households cooking fuel choice in Ouagadougou, Burkina Faso, he reported that the fuel wood utilization rate decreases with increasing household income. Similarly, research findings by Arthur et al. (2010), shows that households' wealth determines the transition from biomass to electricity in Mozambique. The amount of daily animal dung use was also affected negatively by amount of income and it was positively affected by size of livestock population.

Table 10: OLS result for fuelwood and animal dung use in Arsi and w/Arsi zones

Dependent $=$ daily fuel wood $(\mathrm{Kg})$

Dependent variable $=$ daily animal dung $(\mathrm{Kg})$

\begin{tabular}{llllll} 
Variables & $\mathrm{B}$ & $\mathrm{t}$-value & Variables & $\mathrm{B}$ & $\mathrm{t}$-value \\
\hline Constant & 5.62 & $3.41^{* *}$ & Constant & 2.37 & $2.41^{*}$ \\
Family size & 0.19 & $2.33^{*}$ & LnIncome & -0.08 & -1.30 \\
Family labor & 0.16 & $2.01^{*}$ & Age & 0.08 & 1.35 \\
Livestock (TLU) & 0.07 & 1.10 & Landholding & 0.12 & $2.0^{*}$ \\
LnIncome & -0.11 & $-1.74^{*}$ & family labor & -0.15 & $-2.41^{* *}$ \\
Age & -0.20 & 3.65 & TLU & 0.89 & $3.64^{* * *}$ \\
\hline F-value 2.381 & & & F-value $=2.27$ \\
Adjusted $\mathrm{R}^{2}=0.017$ & & Adjusted $\mathrm{R}^{2}=0.015$ & & \\
\hline$* *$ * & & &
\end{tabular}

**, *significant at 5 and $10 \%$ probability level

\section{Constraints and opportunities of existing energy resources in Arsi and W/Arsi zones}

The major energy types under use are commonly biomass sources from different sources majorly woods, animal dung crop residue and others. From result of focus group discussion with all stakeholders at different stages, the rate of deforestation due to use of biomass as a source of household bio-fuel is higher than rate of reforestation in Ethiopia (there is unbalanced utilization of forest). The expansion of agricultural land is also one of the most important causes of deforestation and as a result in most districts where this survey was conducted, every marginal land was distributed as a farmland and deforested. Other studies done by different authors also revealed the same result. For instance the research by Gessesse and Christiansson (2008) in South-central Rift Valley and Bedru (2006) in central and southern Rift Valley of Ethiopia show the impact of farmland expansion on deforestation. Furthermore, as it is know in a mixed farming system the livestock and crop production are supplementary and byproducts from one enterprises is an input for the other and vice-versa. But due to the lack of fuel-wood from forest everything from livestock or crop production goes to fire and the fertility of soil is highly affected.

Only few households are using solar cells for lighting but compared to its starting time, the overall 32 percent of respondents is not insignificant number (table 6). The overall use of electricity use is only 6 percent which insignificant and limited to villages which are somehow condensed. Grid rural electrification is difficult due to high cost of initial investment since the population is scattered. Moreover, the attempt to improve the efficiency of the biomass through use of improved technologies like improved cook stove is not effective.

Good energy utilization opportunities in study areas are that there is gradual increase in rural households' awareness on importance of clear energy and health related problems of using biomass energy sources with open inefficient technologies which is creating demand for improved technologies. This will in turn make the duty of demonstrating technologies easier for both research centers and development practitioners. Moreover, the rural households understand the effects of using biomass in unsafe ways and deforestation and there is good start in biological conservation (afforesting the degraded land) and this will rehabilitate the stock of biomass in general. For instance the respondents were asked whether they know the corresponding effects of using firewood/other biomasses in open stoves or over utilization of forest in unsafe and improper ways for cooking on health, environment (deforestation, rain pattern, time of raining, amount of rain we receive, etc and almost 70 percent of the respondents answered that they know it but they don't have an alternatives to improve their ways of living.

An attention given by Federal Government of Ethiopia for energy development and distribution is which is supported by good energy policy and involvement of different NGOs such as solar energy foundation (German NGO), Hunde working in Oromia on biogas installation and other working on varies energy alternatives are also another opportunities. Ministry of Water Irrigation and Electricity is also investing on energy plant plantation like jatropha in potential areas like Merti, Jeju and Gololcha districts of Arsi zone which is an additional opportunity 
for development of clean energy in the study area.

\section{Limitations in Use of Improved Technologies: Key Challenges}

Even though there is an attempt to demonstrate and disseminate improved cooking stoves like mirt, gonzie and others, it is not as per the plan due to budget shortage, continuous structural changes in development offices and mandates of rural development agents. Previously, natural resource conservation experts at village level were responsible for conservation of forest and dissemination of improved cook stoves at village level but currently since the dissemination of improved cook stoves responsibility is shifted to mineral, water and energy offices at different level, and they don't have representative development agents down level (village), it becomes a forgotten business at PA level.

The lower use of improved cook stoves is associated to many socioeconomic and institutional issues. The first critical reason was lack of awareness on effects of traditional energy using on health amount of biomass to be consumed and natural resource degradation (specially both backyard and natural forest). The second reason for low use of ICS was technology supply shortage. Even though there an attempt to organize ICS producing microenterprises in most districts, the production and distribution are limited to urban and peri-urban areas where there is alternative energy sources and this is due to poor access to infrastructure and logistics.

The third reason for lower adoption (dissemination) of ICS was low purchasing power of the users due to low income. The other reasons for low dissemination of the technologies reported by rural energy offices at zonal and district level were lack of logistics and budget shortage.

The use of biogas is still at demonstration stage by different NGOs and government projects and the number of plants constructed so far is still insignificant. Oromia Biogas Construction Unit is constructing biogas for farmers in cost sharing mode and there are also some NGOs like Hunde Oromo which are funding full cost of the project. According to reports from zonal offices of energy only 849 and 329 bio-gases were constructed in Arsi and w/Arsi zones respectively. Major constraints in biogas dissemination are affordability (expensiveness of the technology), lack of technical gap from constructors (due to this it was reported that most biogas plants are not functional and this goes to 25-30\%), and lack of awareness from users side on advantages of biogas's bi-product (slurry), and incompleteness of the technology (there is no mitad which widely used for baking of injera and other food and it is only used for stew and coffee making and lightening purpose). But currently there is solar cell for lightening purpose as an option and absence of this stove is a critical problem to be solved by research.

Literatures revealed that, being a thirteen-month shine country, the potential solar energy in Ethiopia is 5.5 $\mathrm{Kw} / \mathrm{M}^{2}$ and less than 1 percent was exploited so far (Dereje D., 2013). But the use of solar energy for lightening purpose is constrained by technical gap of users and forged product of (fraudulently reproduced fake/copied products) solar cells which are imported illegally. The supply from government side with collaboration of Ethiopian Development Bank has no consistency and not accessible when farmers demand. In most cases there is no or too limited after sales services. From the result of KII and FGD it was understood that there is no trained technicians to train users even how to install and there is no maintenance service in case of any damages. The report from assessment done by solar energy foundation in 2006 also revealed that these abovementioned constraints were main challenges in solar cell use business (Samson T., 2016). The assessment made at national level described the main challenge in the sector as shortage of hard currency for import, shortage of finance both at local and abroad, bad product quality in the market and inappropriate competition, and fake and coped product import due to lack of national standard and control.

\section{Conclusion and Potential Research and Development Intervention Recommendation Areas in areas of rural energy}

To enhance efficiency and sustainability of the existing energy resources of the area, different research activities has to be conducted and in meantime, intervention with existing at hand technologies that can enhance efficiency of the energy sources is also a crucial.

With at hand existing technologies both research and development bodies can work on demonstration and pre-scaling up of the improved cook stoves, organizing technical and operational trainings for users and local technicians on solar energy apparatus and biogas utilizations. This will increase the awareness of the households on importance of using clean energy and how to use/operate the improved energy source technologies at their home. Local technicians equipped with skill and knowledge of these technologies can also boost the confidence of rural households to invest on such technologies. The study area specially the lowland areas of Arsi are ideal sources of solar energy. For example Dera district was one of the nationally recommended sites for solar PV development in Ethiopia. In addition, districts like Merti, Gololcha, Jeju and zuway-dugda from Arsi zone and Shalla and Arsi Negelle from w/Arsi zone are examples of districts with higher potential for solar energy. Therefore, demonstration of existing ones and researching on different solar cooking technologies is crucial work of research centers to make use of this large renewable energy resource. Developing "injera mitad"/Stove for biogas which was started by Asella agricultural engineering research center, development of energy plant like 
jatropha processing technologies and efficient technology for jatropha oil combustion are areas which need research intervention in near future. There are also potential small scale hydropower generation units in the study area. For example in Arsi zone currently it was reported that there are seven water mills that can be used for electrical energy generation purpose. Therefore, designing and developing appropriate water turbine for these small scale hydropower should be also one of the research area.

\section{References}

[1] Arthur, M. F. S. R., S. Zahran, and G. Bucini. 2010. "On the adoption of electricity as a domestic source by Mozambican households." Energy Policy 38 (11):7235-7249.

[2] Bansal, M., R.P. Saini, and D.K. Khatod. 2013. "Development of cooking sector in rural areas in India-A review." Renewable and Sustainable Energy Reviews 17:44-53.

[3] Bedru Sherefa, 2006. Remote Sensing and GIS for Land Cover/ Land Use Change Detection and Analysis in the Semi-Natural Ecosystems and Agriculture Landscapes of the Central Ethiopian Rift Valley. PhD Thesis. Technische Universität Dresden, Fakultät Forst- Geo-und Hydrowis senschaften, Institut für Photogrammetrie und Fernerkundung, Dresden.

[4] Chaudhuri, S., and A.S.P. Pfaff. 2003. Fuel-choice and Indoor Air Quality: A Household-level Perspective on Economic Growth and the Environment. New York: Department of Economics and School of International and Public Affairs, Columbia University.

[5] Dawit Diriba Guta (2012). Assessment of Biomass Fuel Resource Potential and Utilization in Ethiopia: Sourcing Strategies for Renewable Energies. International journal of renewable energy research, Vol.2, No.1, 2012

[6] Eric Martinot, Akanksha Chaurey, Debra Lew, Jos'e Roberto Moreira, and Njeri Wamukonya, 2002. Renewable Energy Markets in Developing Countries.

[7] Gessesse ,D. and Christianson, C. 2008. Forest decline and its causes in the south-central Rift Valley of Ethiopia: Human impact over a one hundred year perspective. Ambio; 37(4): 263-271.

[8] Heltberg, R. 2005. "Factors determining household fuel choice in Guatemala." Environment and Development Economics 10 (03):337-361.

[9] Nlom, J.H., and A.A. Karimov. 2014. Modeling Fuel Choice among Households in Northern Cameroon. Working Paper 2014/038. Helsinki: World Institute for Development Economics Research (WIDER).

[10] Ouedraogo, B. 2006. "Household energy preferences for cooking in urban Ouagadougou, Burkina Faso." Energy Policy 34 (18):3787-3795.

[11] Samson Tsegaye, 2016. Highlights of the Ethiopian Energy Sector. Accessed online from: https://www.unosd.org/content/documents/17599.\%20Ethiopia\%20Energy\%20Sector\%20Highlight $\% 20 \mathrm{Fe}$ bruary\%202016\%20main.pdf.

[12] Dereje D., 2013. Ethiopia's Renewable Energy Power Potential and Development Opportunities. Ministry of Water and Energy June 22, 2013 Abu Dhabi, UAE . Accessed from: https://www.ctc-n.org/sites/www.ctcn.org/files/resources/africa_cec_session_3_ministry_of_water_and_energy_ethiopia_beyene_220613_0.pdf.

[13] Abate Feyissa Senbeta, 2009. Climate Change Impact on Livelihood, Vulnerability and Coping Mechanisms: A Case Study of West-Arsi Zone, Ethiopia. MSc. Thesis Submitted to Lund University Masters Program in Environmental Studies and Sustainability Science (LUMES)

\section{Appendix}

Appendix I: Conversion factors used to estimate TLU

\begin{tabular}{ll} 
Types of animals & TLU \\
\hline Cow & 1 \\
Ox & 1 \\
Bull & 1 \\
Heifers & 0.75 \\
Café & 0.40 \\
Sheep/ Goat & 0.10 \\
Donkey & 0.50 \\
Horse/ mule & 0.80 \\
Camel & 1
\end{tabular}

Source: (Storck, et al., 1991) and Freeman et al., (1996) 
Appendix II: Conversion factors used to estimate adult equivalent

\begin{tabular}{lll} 
Age group & Male & Female \\
\hline$<10$ & 0 & 0 \\
$10-13$ & 0.2 & 0.2 \\
$14-16$ & 0.5 & 0.4 \\
$17-60$ & 1 & 0.8 \\
$>60$ & 0.7 & 0.5
\end{tabular}

Source: Bekele Hundie (2001) 